\title{
A Case Study for Lightning Scenario and Awareness Building in Bangladesh
}

Ferdous Ahmed ( $\nabla$ ferdous.ahmed@iubat.edu )

IUBAT: International University of Business Agriculture and Technology https://orcid.org/0000-00018737-8142

\section{Research Article}

Keywords: Lightning Scenario, lightning Casualties, lightning Vulnerabilities, Awareness building, conceptual framework

Posted Date: May 13th, 2021

DOI: https://doi.org/10.21203/rs.3.rs-407391/v1

License: (1) This work is licensed under a Creative Commons Attribution 4.0 International License. Read Full License 


\section{Abstract}

Lightning frequencies have increased recently to an alarming way during the monsoon and summer periods in Bangladesh. As a result it has to accept an annual average death toll of 200-300 people from the lethal lightning strikes in the last decade. Observing the consequences of these lightning causalities, it has been considered as one of the natural disasters since 2016. A secondary data sources have been applied in this study. From observations it found that the northeast regions are mostly affected and farmers and fishermen are the most vulnerable groups to lightning fatalities. The aim of this research to introduce a conceptual model to build lightning awareness to combat lightning fatalities in Bangladesh. This policymakers of Bangladesh could think seriously how to implement this lightning awareness building effectively diminishing the enormous causalities.

Keywords: Lightning Scenario, lightning Casualties, lightning Vulnerabilities, Awareness building, conceptual framework.

\section{Introduction} calamities, of which floods and cyclones are the most devastating (Alam et. al., 2017; Mawla, et al. 2018; Holle, et. at., 2018; Chakravorti et al., 2018; Farukh, et. al., 2017; Dewan, et. al., 2018; Yadava et al., 2020). Because of the extensive scale of damage associated with floods and cyclones, natural hazards such as lightning often receive little attention (Ono and Schmidlin 2011). lightning fatalities during short periods in Bangladesh (Holle et al., 2019; Biswas, et. al., 2016; Umakanth, et. al. 2020; Karmakar et. al., 2020). Recently, following the shocking deaths of 89 people across the country in 2 days (12 and 13 May) in 2016, the government of Bangladesh declared lightning a natural disaster and mandated the collection of information on lightningrelated injury and fatality (Dewan et al 2017; Khatun,) et. al., 2016). The annual average death toll has been augmented in the last five years to what is 500 to 600 people due to lethal lightning strikes. Apart from these death tolls, a number of injuries has also increased simultaneously throughout Bangladesh (DDM, 2019). The incidence of lightning fatalities in Bangladesh is 0.9 
per 1,000,000 populations per year, which is higher than in high-income countries (Holle RL

33 2010). It has among the highest death rates in the world from catastrophes like lightning (Schmidlin, 2009). It also has the intermediate annual death rate 0.5 to 5.0 per million population (D.M. Elsom 2018). About 5468 lightning related casualties consisted of 3086 deaths, and 2382 injuries were reported from 1990 to 2016 (Dewan et al., 2017). In order to manage and minimize the risks associated with this weather-related hazard in Bangladesh, an understanding of the environmental characteristics of lightning occurrence is of great importance (Dewan et al. 2017; Dewan et al. 2018). However, recent years, lightning strike incidents are becoming more frequent and claiming more lives than in the past. (Uddin and Suravi, 2018).

A total of 1,476 people have died from lightning in Bangladesh during 2010-2016 (VOA News

42 2016). Lightning is fast and very hot while thunder can usher in heavy rain and strong winds, but lightning is more dangerous and destructive than thunder. According to the National Geographic, lightning storms in Bangladesh occur mostly in May and in the afternoon, when the temperature is high (Islam and Schmidlin, 2020; Dewan et al 2017). As per our record of the Meteorological Department of Bangladesh, lightning frequency is increasing gradually since 1981 due to climate variability and increase in temperature. Meteorological Department, indicated that Bangladesh experiences lightning strikes mainly during pre-monsoon period of April-May, each of the years where climate change is contributing to its increased intensity. In 2017, the death toll was 59 in May only (Farukh et al, 2017; Biswas, et. al, 2020). In this country, the climatology of lightning strikes demonstrated that almost $62 \%$ flash computed during the pre-monsoon season (Dewan et al. 2018). It is identified that in Bangladesh most fatalities occurred between early morning and early evening, and 93 percent of the fatalities occurred in the rural parts of Bangladesh (Dewan et al 2017). Bangladesh is experiencing a disproportional increase in casualties from lightning strikes in the recent decade.

As per the statistics of the Department of Disaster Management (DDN) the total death toll is 828 from 2010 to 2016. But in reality, the actual fatalities are even more due to the lightning scenarios. Several categories of people like farmers, fishermen, livestock ranchers are highly vulnerable to the lightning hazards in Bangladesh. These categories include farmers working in subsistence agriculture, lightning-unsafe dwellers and the people who are working in lightning unsafe structures (Holle and Cooper 2016; Yadava, et al. 2020). Climate change is apparent in the 
changing rainfall and temperature patterns globally (Zscheischler,. et. al., 2018; Stoknes, 2015; Schmidlin, T. W. 2009). Some relevant research claims the number of deaths caused by thunder and lightning has increased in the last eight years, reaching 1800 in total; this is the all-time highest death rate caused by lightning strikes. According to Indian Weather Office and Japan Aerospace Exploration Agency, 2400 lightning strikes take place on average in Bangladesh every year.

Therefore, it is also believed that climate change factor has great influence on augmenting lightning scenarios in Bangladesh. But in reality it is not evidenced that global warming and climate can worsen lightning disasters. Moreover, there is no research studies found in Bangladesh which proved climate change augmenting the lightning scenarios in Bangladesh. But some of the researchers they think change of climatic patters could be a potential to worsen lighting fatalities here. According to Govorushko (2012), Bangladesh is experiencing very high frequencies of lightning and thunderbolts due to extreme temperature during the summer and monsoon, especially in the north-east regions which occupies the vast water bodies such as Haor areas. Generally, the most temperature rises are in April of each year in Bangladesh, which is caused by water vaporizing leading to rain, clouds, and lightning. As per the study of Schmidlin (2009), Bangladesh is the hotspot to create more lightning frequencies and thunderbolts in the Indian subcontinent which occurs an average of 40 lightning strikes per square kilometer during the monsoon. According to the statistics, compiled by Foundation for Disaster Forum (FDF, 2019), the death toll from lightning strikes was 179 in 2011, 301 in 2012, 285 in 2013, 210 in 2014, 186 in 2015, 245 in 2016, and 205 in 2017.

North-east and western parts of Bangladesh are hotspots for lightning strikes where Sylhet and Rajshahi divisions are located. The lightning frequencies are becoming common phenomena in the recent years due to the climate change and overwhelming warm moisture in the atmospheric conditions. Since the lightning hazards are increasing at an alarming rate, each of the years in a particular period therefore it is a great concern of the government as well as the communities. Therefore the aim of this research is to find the suitable policy recommendations to build awareness among communities to diminish the fatalities rate though proper policy implementations. This awareness building will be a participatory approach among different stakeholders under six different ministries though effective partnerships to reduce lightning causalities in Bangladesh. 
94 This is a case study where to check the current lightning scenario of Bangladesh. It mostly considered secondary data sources like professional literature and local newspapers. Last ten (10) years local daily newspaper articles as well as published research papers ae considered deliberately. Some of the rational database also has been extracted from different local newspapers. Since government databases are not appropriately organized or unavailable to get the access so this research riled more screening daily newspapers which found organized and rational data sources for last decade. A rigorous and extensive table was managed to collect day to day lightning incidents. However based on these collected data it detected the no of fatalities and causalities; no of the annual lighting frequencies, activities during lightning strike; mostly affected districts in Bangladesh in recent decade. A conceptual framework has been created for building awareness among communities having partnerships including six ministries in Bangladesh. Finally policy recommendations has been made for result oriented implementations.

\section{Discussion}

Observing the fatal causalities by lightning strikes is a new natural disaster in Bangladesh since 2016. Although this is natural disaster, mitigating anthropogenic behavior as well as addressing government policy might help the condition to reduce the overall death toll. This is apparent that last five years the frequencies of the lightning increased overwhelmingly in Bangladesh. This is quite rational that due to global warming Bangladesh is also experiencing the change of climatic pattern in the recent decade. The normal trends of rainfall and temperature are fluctuating overwhelmingly. Moreover, the number of the storms, cyclones or tornadoes are escalating due to uncommon rainfall and temperature phenomena. Although there is no recent study to find the connection between climate change and lighting fatalities but it is evidenced that Bangladesh is experiencing more lethal lightning frequencies during the monsoon season. Bangladesh has a subtropical monsoon climate characterized by wide seasonal variations in rainfall, temperatures and humidity. There are three distinct seasons in Bangladesh: a hot, humid summer from March to June; a cool, rainy monsoon season from June to October; and a cool, dry winter from October to March. But due to the global warming and climate change the regional monsoon patterns also have changed which causes more fatal lightning in Bangladesh. 
124 From the figure $1 \& 2$ both the fatalities and causalities have been observed of the last five years 125 (5) years (2015-2019) in the 64 different districts. This study found that the number of death toll 126 is significantly higher than the number of injured people. The districts of Sunamgonj and Habigonj 127 (Northeast Region) are mostly affected by the lethal lightning which caused largest consecutive 128 number of death tolls. On the other hand, Dhaka and Sunamgonj districts experienced most of no 129 of injuries from 2015-2019. These figures also represent that Bandarbon and Bhola stands for least 130 number of death tolls whereas a good number of districts like Baguna, Bhola, Chattagram, 131 Faridpur, Jahsore, Lakshimpur, Nilphamari, Naraynagonj, Patuakhali, Sherpur, Shariotpur and 132 Tangail affected by least number of injuries. From the observations of the last five years (2015133 2019) data this study also found that 102 people died from lightning in north eastern region 134 whereas 33 people were injured from different lightning strikes. However, Sirajganj and Satkhira 135 districts experienced the least fatalities by the lightning. It can be argued that the topography of 136 Satkhira is close to the largest mangrove forest of the world (Nice Forest) which actually helping 137 those area making huge canopy or neural vegetation. This is the natural forest which area is 10,000 $138 \mathrm{~km}^{2}$ and most plants number are Heritiera fomes. This forest cover helping to reduce the lighting 139 frequencies. 


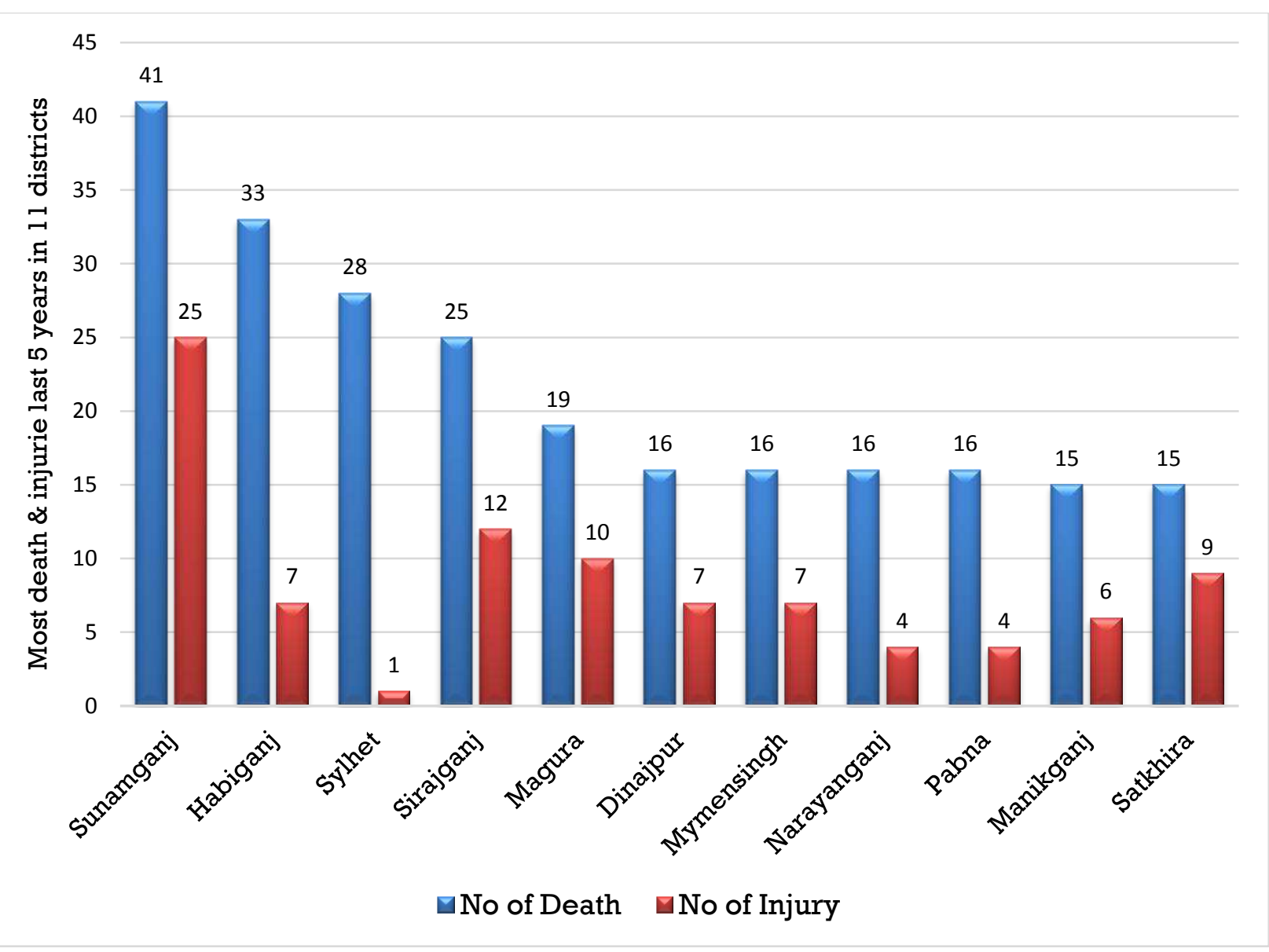

Fig. 1: Most Lightning causalities in ten different Districts in Bangladesh (2015-2019)

142 However this is research also compared the last five years (2015-2019) causalities throughout 64 143 districts under ten divisions. It indicates different fluctuations comparing the death toll and injuries.

144 The most fatalities were evidenced in 2012 where number of deaths toll was 301 . However, the 145 most injury level was found in 2016 which is 245. But the recent year (2019) death toll seems 146 increasing which is 248 which is quite alarming for human death caused by lightning. This 147 comparative study highlights that may be in the near future Bangladesh will experience more 148 lightning scenarios due to climate change factors. Since Bangladesh predicts more lightning 149 fatalities, therefore it requires more concentration from both government side and other 150 stakeholders to diminish the damage level building awareness among communities. 


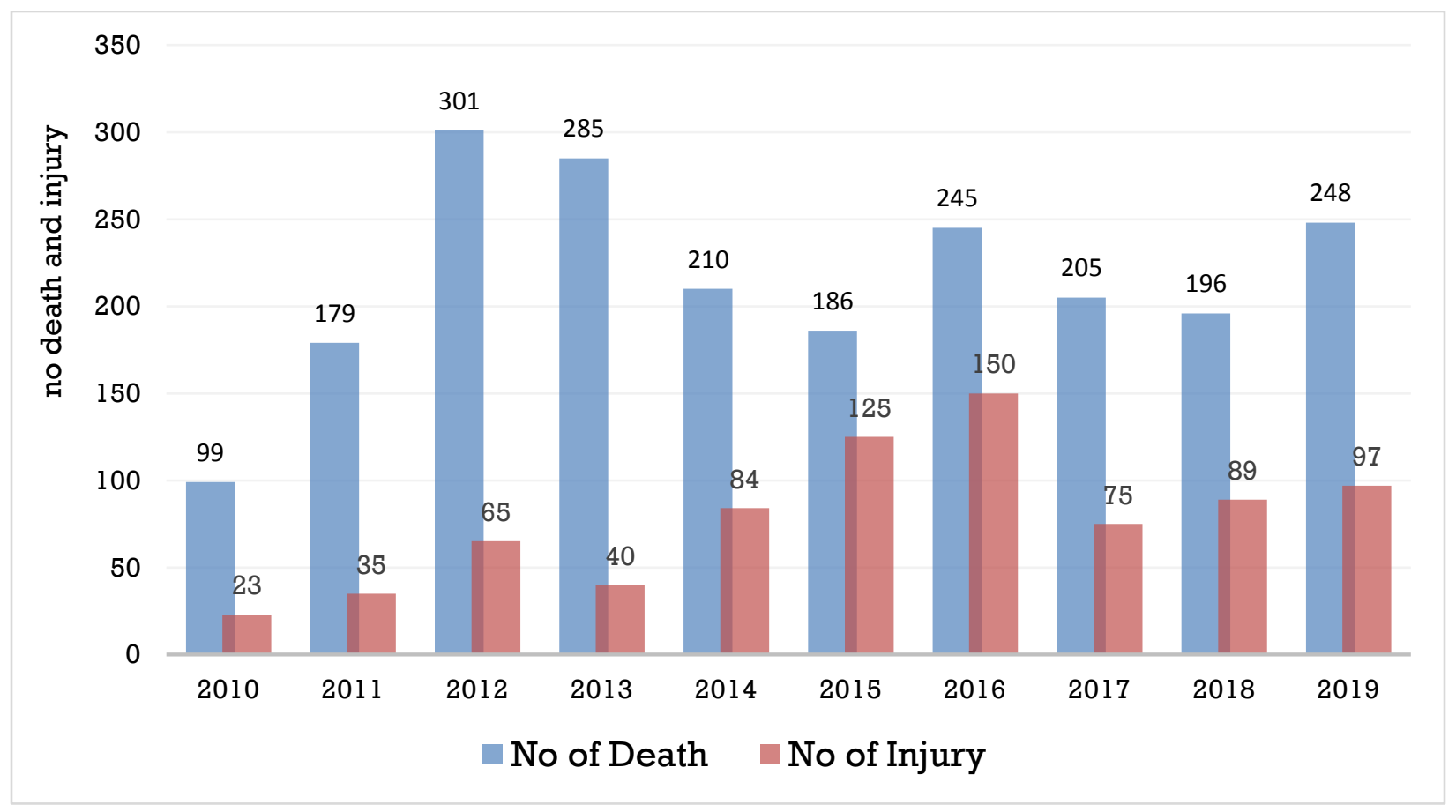

Fig. 2: Comparative Causalities from Lightning (2010-2019) in Bangladesh

154 Fig. 3 indicates the different working activities when lightning struck casing the causalities in the 155 different parts of Bangladesh. Based on the examined lightning records it found that nine different 156 activities were mostly common while lightning caused fatalities among communities. Among 157 those common activity indications of the last five years (2015-2019) it has been observed that 158 during outside activities most people are affected from lighting strikes such as harvesting paddy 159 or working croplands, fishing and working in the jute fields. The significant fatalities also observed 160 during stuck by rain where people took shelter under the tree or tea stalls. However, the least 161 fatalities are recorded from staying home without outside activities. Playing outside also recorded 162 significant causalities where mostly young guys and children are affected by lightning. 


\section{$\begin{array}{ll}\text { Returning Home } \\ \underbrace{n}_{0} & \text { Caught by Rain }\end{array}$ \\ At Home \\ Playing Outside \\ Fishing \\ Working in Jute Field \\ 일 \\ Working in Paddy Field \\ Working in Crop land}

Harvesting Paddy
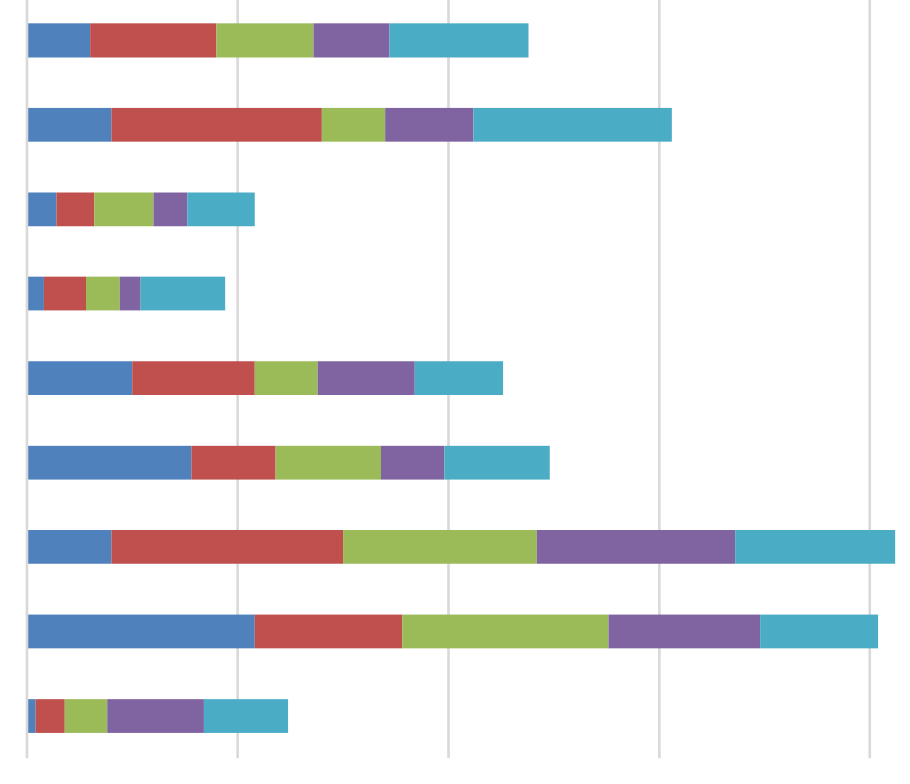

150

200

250

$\square 2015 \square 2016 \square 2017 \square 2018 \square 2019$

Fig.3: Lightning Fatalities during Different Activities (2015-2019)

Figure 4 highlighted the lightning frequencies of last five years (2015-2019 in Bangladesh. It has been studied that generally the lightning strikes occurred from April to October each year. The most frequencies are recorded in the month of April to July in the different regions of Bangladesh. Particularly the month of occurs most lightning frequencies in the recent years. It is also has been evidenced that the year 2018 got most lightning frequencies throughout Bangladesh. In addition, these lightning frequencies usually experience just before starting the monsoon period in the early summer time. The north wind blow does not carry that much cloud that is why in winter season the least number of lightning frequencies are experienced in that time period. Figure 5 specifies the total distribution of the causalities in different ten (10) divisions in last five years (2015-2019). Apparently Sylhet division recorded the most death toll (109). On the other hand Rajshahi division experienced second most fatalities (93). However Chattagram division recorded lowest death toll caused by lightning strikes. It is urge to study further to investigate why northern part experiencing most fatalities in the recent years. It requires more scientific study with the application of suitable technology so that the researchers can reach into an opinion. 


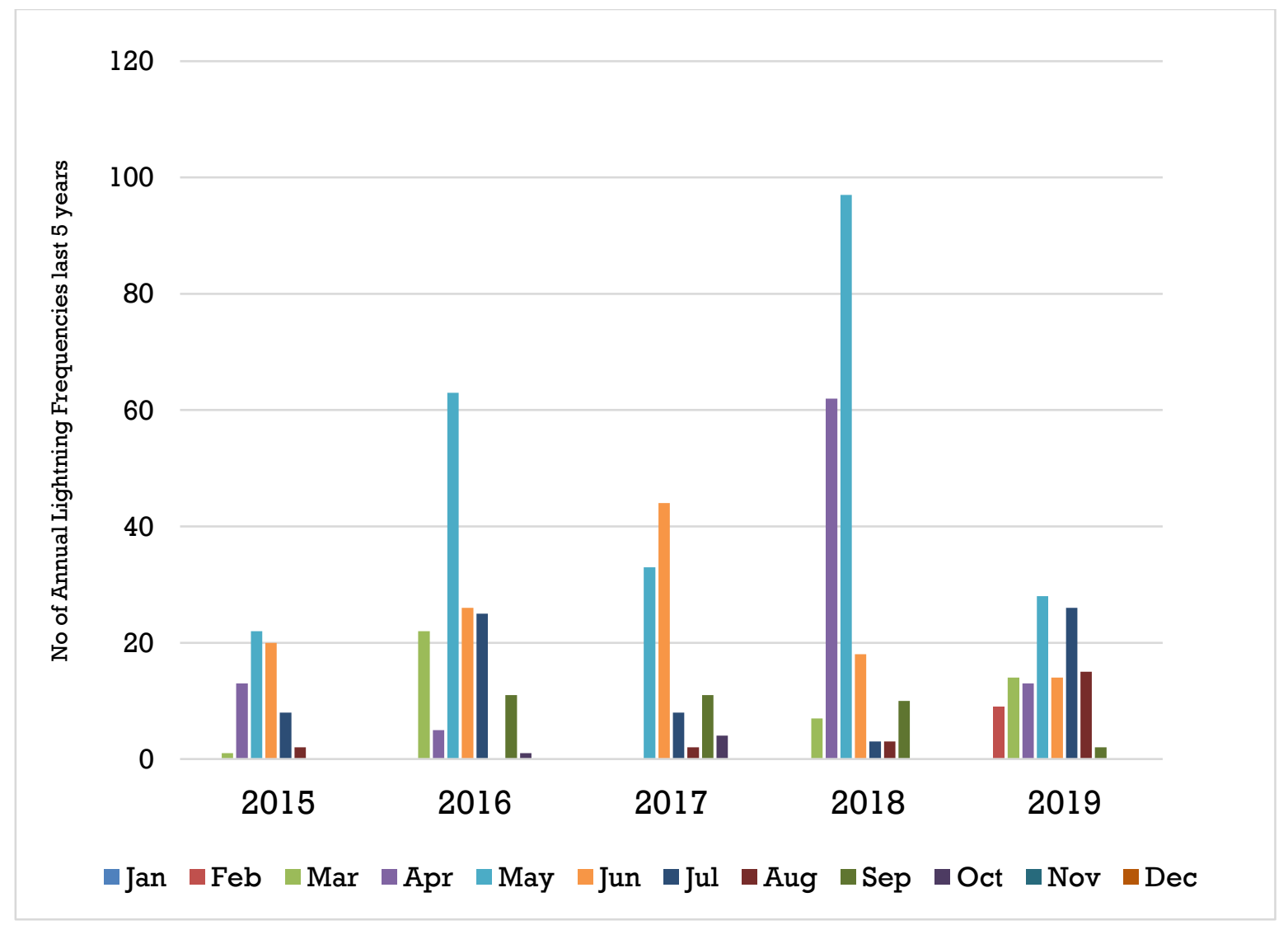

Fig.4: Annual Lightning Frequencies (2015-2019)

184

185

186

187

188

189

190

191

192

193

194 
Fig 5: Death toll from Lightning in Major Divisions (2015-2019)

\subsection{Conceptual Model Building Awareness to Reduce Lightning Fatalities}

215 Based on the research objective this study produced a conceptual model (Fig. 6) to reduce the lightning fatalities in Bangladesh. Because the application and implementation of technologies are too far away to get the significant benefits to diminish lightning causalities. In fact there are no

218 alternatives to build awareness among vulnerable groups like farmers, fishermen, youth and community people. Due to the lack of basic concepts in and among communities about the

220 lightning and minimum precautions, many people die or are injured in recent years. The time lag 221 between lightning and thunder will allow one to understand how far away is the thunder and 222 pending lightning. If the time between each thunder gradually decreases, that would mean the 223 thunder is coming nearer to the farmer. With this knowledge, he or she has to rush faster to find 
224 nearby shelter. While going to work in the field, farmers should carry a wooden or plastic tool with

225 them. It is safe to wear rubber shoes on foot. If the time between each thunder increases gradually,

226 that would mean the thunder is going away from that particular zone. Farmers should be aware

227 about the 30:30 formula (Shykh Seraj, 2018). That means if the sound of lightning is heard after

22830 seconds of seeing it would mean thunders are nearby. Then, the farmer must take shelter at a

229 safe place and wait there for thirty minutes. If anyone takes shelter under a big tree, he/she must

230 maintain the distance 10 to 12 feet away from the root of the tree.

231

232

233

234

235

236

237

238

239

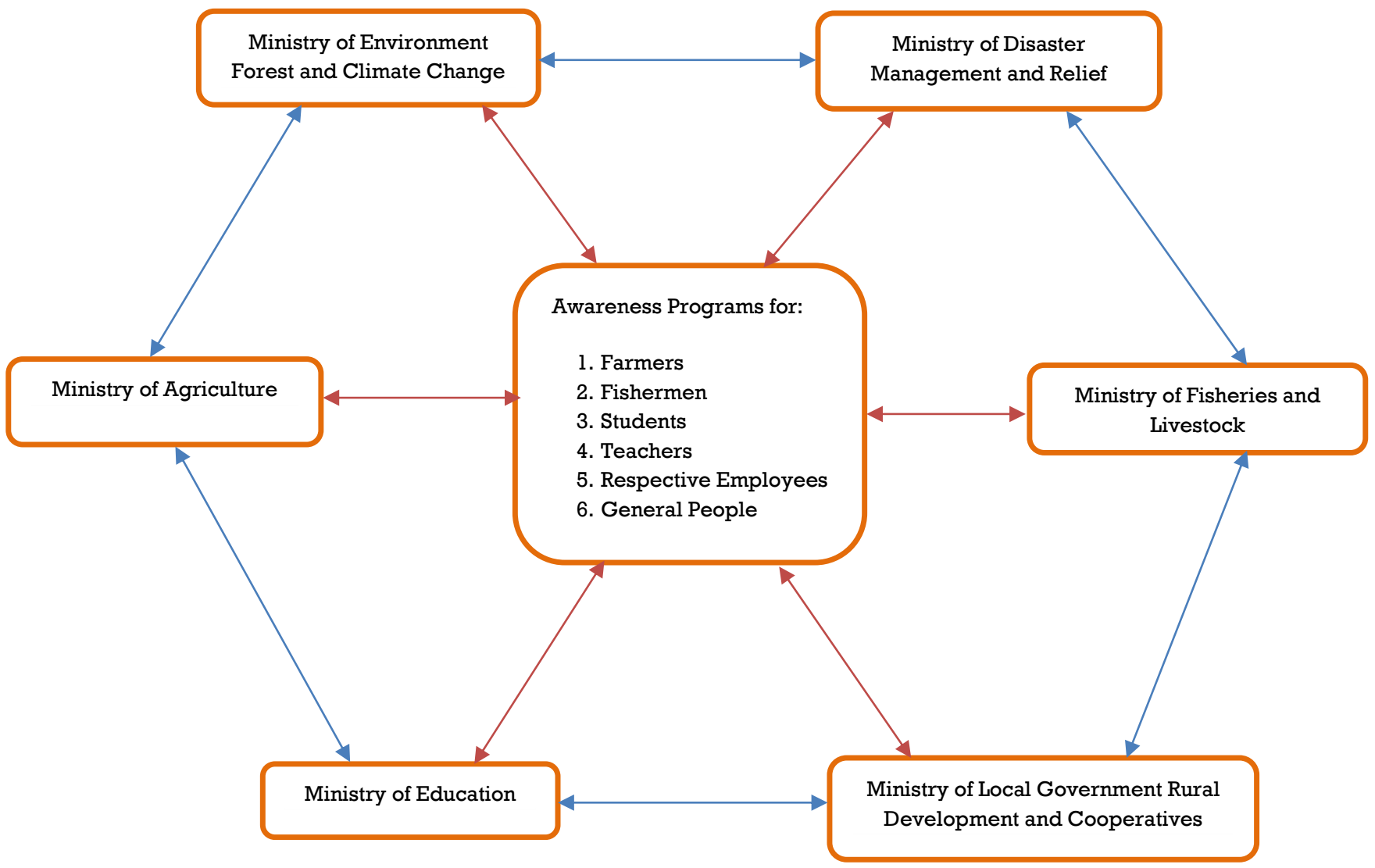

Fig 6: Conceptual Model of Building Awareness for Lightning Fatalities in Bangladesh

243 To implement this awareness building program Govt. should introduce a National Taskforce

244 including the Ministry of Agriculture, the Ministry of Environment, Forest and Climate Change,

245 the Ministry of Disaster Management and Relief, and the Bangladesh Meteorological Department, 
Ministry of Education, Ministry of Local Government Rural Development and Cooperatives and Ministry of Fisheries and Livestock. The figure (no) indicates that the awareness building is not an easy job to implement successfully, therefore collaborative partnerships can play a vital role in Bangladesh to diminish the lightning causalities This taskforce will ensure the awareness programs are administered at different levels among communities: a) awareness training program for farmers, b) awareness training program for village people, c) awareness training program school children and young people, and d) awareness building training for fishermen. Awareness building among school children and young people is very important because during rainy day most of them prefer to play outdoor sports like football and other activities. Recently there are so many fatalities observed where children or young people were playing outside during lightning strikes. It has been reported from most of the other researches that the farmers, fishermen, livestock ranchers and children playing outside are mostly vulnerable to lightning strike. That is why the six different ministries, meteorological department included their affiliated organizations can some awareness and training programs that how to escape from lightning fatalities while different people working outsides. Each of the ministries along with its affiliates it has some public functions or connections based on their daily activities.

As an example Ministry of Agriculture and its affiliated organizations along with their daily activities they may invite a group a farmers by rotation is a particular place in Bangladesh those are vulnerable to lightning incidents. From the Fig. 6 already we came to what are hotspots for lethal lightning here. Similarly Ministry of Fisheries and Livestock also can offer this kind of awareness programs for the fishermen which are the second most vulnerable to lightning damage. However Ministry of Education also can take the same responsibility to teach students of all sections (Primary-Secondary-Tertiary Levels) when not to play outside and how they can realize observing the weather patterns. This is how it is easy to understand that the only awareness building programs can reduce the lightning vulnerabilities. Because use of technology is still far away to be implemented due to lack of socioeconomic conditions. Table -1 gives us clear feature that how different ministries can work together with its affiliated organizations building awareness programs to reduce lightning fatalities among respective stakeholders. 
Table: List of Ministries and Affiliated Organizations for Lightning Awareness Program

\begin{tabular}{|c|c|c|}
\hline SI & $\begin{array}{c}\text { Ministry for Participatory } \\
\text { Awareness Programs }\end{array}$ & Organizations to Implement Awareness Programs \\
\hline 1 & $\begin{array}{l}\text { Ministry of Environment } \\
\text { Forest and Climate Change }\end{array}$ & $\begin{array}{l}\text { 1. Department of Environment (DoE } \\
\text { 2. Department of Forest (DoF) } \\
\text { 3. Bangladesh Forest Research Institute (BFRC) } \\
\text { 4. Bangladesh Forest Industries Development } \\
\text { Corporation (BFIDC) } \\
\text { 5. Bangladesh National Herbarium } \\
\text { 6. Bangladesh Climate Change Trust } \\
\text { 7. Bangladesh Rubber Board } \\
\text { 8. Bangladesh Forest Research Institute }\end{array}$ \\
\hline 2 & Ministry of Agriculture & $\begin{array}{l}\text { 1.Department of Agricultural Extension } \\
\text { 2.Bangladesh Agricultural Development Corporation } \\
\text { (BADC) } \\
\text { 3.Bangladesh Agricultural Research Council } \\
\text { 4.Bangladesh Agricultural Research Institute } \\
\text { 5.Bangladesh Rice Research Institute } \\
\text { 6.Bangladesh Jute Research Institute } \\
\text { 7.Bangladesh Sugar crop Research Institute } \\
\text { 8.Bangladesh Institute of Nuclear Agriculture (BINA) } \\
\text { 9.Cotton Development Board } \\
\text { 10. Agricultural Information Service (AIS) } \\
\text { 11. National Agricultural Training Academy (NATA) } \\
\text { 12. Department of Agricultural Marketing(DAM) } \\
\text { 13. Seed Certification Agency (SCA) } \\
\text { 14. Barendra Multi Development Authority (BMDC) } \\
\text { 15. Bangladesh Institute of Research and Training on } \\
\text { Applied Nutrition } \\
\text { 16. Soil Research Development Institute } \\
\text { 17. Bangladesh Wheat and Maize Research Institute } \\
\text { 18. Horticulture Export Development Foundation }\end{array}$ \\
\hline 3 & $\begin{array}{l}\text { Ministry of Fisheries and } \\
\text { Livestock }\end{array}$ & $\begin{array}{l}\text { 1.Department of Livestock } \\
\text { 2.Department of Fisheries } \\
\text { 3.Bangladesh Livestock Research Institute (BLRI) } \\
\text { 4.Bangladesh BFRI } \\
\text { 5.Fisheries and Livestock Information Department } \\
\text { 6.Marine Fisheries Academy }\end{array}$ \\
\hline
\end{tabular}




\begin{tabular}{|c|c|c|}
\hline & & $\begin{array}{l}\text { 7.Bangladesh Veterinary Council } \\
\text { 8.Bangladesh Fisheries Research Institute } \\
\text { 9.Bangladesh Fisheries Development Corporation }\end{array}$ \\
\hline 4 & $\begin{array}{c}\text { Ministry of Disaster } \\
\text { Management and Relief }\end{array}$ & Department of Disaster Management \\
\hline 5 & $\begin{array}{l}\text { Ministry of Local Government } \\
\text { Rural Development and } \\
\text { Cooperatives }\end{array}$ & \begin{tabular}{|ll} 
1. & Union Porishad \\
2. & Upazilla Posishad \\
3. & Zilla Posishad \\
4. & Municipality \\
5. & City Corporation
\end{tabular} \\
\hline 6 & $\begin{array}{c}\text { Ministry of Education \& } \\
\text { Ministry of Primary and Mass } \\
\text { Education }\end{array}$ & $\begin{array}{l}\text { 1.Primary Education } \\
\text { 2.Secondary Education } \\
\text { 3.Higher Secondary education } \backslash \\
\text { 4.Higher Education }\end{array}$ \\
\hline
\end{tabular}

\section{Policy Implications and Way Forward}

278 Thus, there is no alternative to being aware for enjoying the benefits of lightning strikes. Farmers 279 and average people are to be taught the methods of protecting themselves from lightning strikes.

280 Especially, it is highly dangerous for farmers who work in open fields. And so, they must consider 281 the protection measures before going to the field during the period of thunderstorms. If farmers 282 are a little aware, they can avoid the risk of losing life even in hostile environment. People involved 283 should think about a comprehensive system of effective security for lightning. Therefore an 284 effective partnership programs between different ministries and stakeholders can play a vital role 285 to initiate a national taskforce are important to look after the current lightning scenarios in 286 Bangladesh. Observing the causalities this conceptual model can be adopted to implement the most 287 significant awareness building among communities. Based on the present socioeconomic 288 condition of Bangladesh can be benefited reducing the lighting fatalities by the awareness building 289 programs in the community. 


\section{Conclusion}

292 It is evidenced that due to drastically change of weather patterns Bangladesh is experiencing more 293 lightning causalities in the recent years. Moreover, the lightning fatalities increased impotently. It 294 is a long debate that how to possible reducing lightning fatalities in Bangladesh. Due to 295 socioeconomic condition still technology application is far away. On the other hand there is some doubt how technology can diminish lightning problem in a vast area. The govt. already studied the

297 pursuit of technology use but finally said as per the costing it does not able to cover huge area for

298 lighting strikes. Therefore, building lightning awareness is the best option that can decrease the

299 lighting causalities in a more expected level. That is why this study introducing a conceptual framework for first time in Bangladesh to combat lightning fatalities. This conceptual, model successfully indicates that how different ministries including its affiliated organizations can come forward to work together building lightning awareness in the community level for the different stakeholders. This study including other literatures clearly states that the farmers, fisher men are the most vulnerable groups to lightning strikes. Thus it is urgent need for awareness building in a more effective way. Nevertheless, the policy makers of Bangladesh government should think seriously about the awareness building where this conceptual framework could a baseline study reducing lightning fatalities and causalities in the coming futures.

\section{Limitation}

309 This study belongs some limitations due to data collections form the secondary data source. The authors mainly relied on daily local newspapers (online version) for the secondary data extraction 311 purpose. Therefore 5\% chance might occur for data dissimilarity compare to other existing sources. 312 Although Bangladesh is experiencing the lighting fatalities since long but no conceptual 313 framework yet produced to address properly the lighting damage adopting awareness building 314 among communities following the participatory approach. But this study first time introduced a 315 conceptual model. This conceptual framework still may have some lacking for more rigorous 316 description how to implement by different ministries. Therefore the authors of this research intend 317 to organize more details of the action plan for awareness building in the next research article.

\section{Acknowledgement}

319 There is no conflict of interest of this research. This is manuscript is solely derived from the selfinitiated project without any research funding or grant support. 


\section{Reference}

1. Alam, E., Dominey-Howes, D., Chagué Goff, C., \& Goff, J. (2012). Tsunamis of the northeast Indian Ocean with a particular focus on the Bay of Bengal region-A synthesis and review. Earth-science reviews, 114(1-2), 175-193.

2. Ashley, W. S., \& Gilson, C. W. (2009). A reassessment of US lightning mortality. Bulletin of the American Meteorological Society, 90(10), 1501-1518.

3. Ayers, J. M., Huq, S., Faisal, A. M., \& Hussain, S. T. (2014). Mainstreaming climate change adaptation into development: a case study of Bangladesh. Wiley Interdisciplinary Reviews: Climate Change, 5(1), 37-51.

4. Bakul Kumar Chakravorti, Prosannajid Sarkar, Atiur Rahman, Atikur Rahman. Thunderstorm and Lightning: the Temperature Effect on Climate Change of Rangpur Region in Bangladesh. Science Journal of Energy Engineering. Vol. 6, No. 2, 2018, pp. 31-36.

5. Chowdhury, E. H., \& Hassan, Q. K. (2015). Operational perspective of remote sensingbased forest fire danger forecasting systems. ISPRS Journal of Photogrammetry and Remote Sensing, 104, 224-236.

6. Cooper, M. A., Andrews, C. J., Holle, R. L., Blumenthal, R. Y. A. N., Navarette Aldana, N., \& Auerbach, P. (2017). Lightning-related injuries and safety. Auerbach's Wilderness Medicine 7th ed. Auerbach P. Elsevier, Philadelphia, 71-117.

7. Dastagir, M. R. (2015). Modeling recent climate change induced extreme events in Bangladesh: A review. Weather and Climate Extremes, 7, 49-60.

8. Dewan, A., Ongee, E. T., Rafiuddin, M., Rahman, M. M., \& Mahmood, R. (2018). Lightning activity associated with precipitation and CAPE over Bangladesh. International Journal of Climatology, 38(4), 1649-1660.

9. Dewan, A., Hossain, M. F., Rahman, M. M., Yamane, Y., \& Holle, R. L. (2017). Recent lightning-related fatalities and injuries in Bangladesh. Weather, climate, and society, 9(3), 575-589.

10. Doljinsuren, M., \& Gomes, C. (2015). Lightning incidents in Mongolia. Geomatics, Natural Hazards and Risk, 6(8), 686-701.

11. Duarah, C. K. (2019). Climate Change \& Increasing Lightning Death in Bangladesh and Northeast. 
12. Dwyer, J. R., \& Uman, M. A. (2014). The physics of lightning. Physics Reports, 534(4), $147-241$.

13. Ghosh, A. (2018). The great derangement: Climate change and the unthinkable. Penguin UK.

14. Gomes, C. (2017). Lightning Related Human Risks and Risk Management. American Journal of Management Science and Engineering, 2(5), 65.

15. Govorushko, S. M. (2012). Meteorological Processes. In Natural Processes and Human Impacts (pp. 87-147). Springer, Dordrecht.

16. Hiwasaki, L., Luna, E., \& Shaw, R. (2014). Process for integrating local and indigenous knowledge with science for hydro-meteorological disaster risk reduction and climate change adaptation in coastal and small island communities. International journal of disaster risk reduction, 10, 15-27.

17. Islam, M. S., \& Schmidlin, T. W. (2020). Lightning hazard safety measures and awareness in Bangladesh. Natural Hazards, 101(1), 103-124.

18. Jacobs, M. (2012). The tropical rain forest: A first encounter. Springer Science \& Business Media.

19. Kohn, M., Galanti, E., Price, C., Lagouvardos, K., \& Kotroni, V. (2011) "Nowcasting thunderstorms in the Mediterranean region using lightning data", Atmospheric Research, 100(4), 489-502.

20. Kreft, S., Eckstein, D., \& Melchior, I. (2016) “Global Climate Risk Index 2017”, German watch, Germany.

21. Madaki, K., \& Sayok, A. K. (2019). Effects of deforestation in Kurmi Local Government Area, Taraba State, Nigeria. Journal of Advanced Research in Social and Behavioural Sciences, 14(1), 16-28.

22. Rahman, S. M. M., Hossain, S. M., \& Jahan, M. U. (2019). Thunderstorms and Lightning in Bangladesh. Bangladesh Medical Research Council Bulletin, 45(1), 1-2.

23. Schmidlin, T. W. (2009). Risk factors and social vulnerability. In Preprints of the international forum on tornado disaster risk reduction in Bangladesh, Dhaka, Bangladesh. Wind Engineering Research Center, Tokyo Polytechnic University.

24. Shykh Seraj, (2018). Protecting farmers from lightning. August 30, 2018, https://www.thedailystar.net/news/country/protecting-farmers-lightning-1626499 
25. Singh, D., Singh, R. P., Singh, A. K., Kulkarni, M. N., Gautam, A. S., \& Singh, A. K. (2011). Solar activity, lightning and climate. Surveys in geophysics, 32(6), 659.

26. Stoknes, P. E. (2015). What we think about when we try not to think about global warming: Toward a new psychology of climate action. Chelsea Green Publishing.

27. Uddin, M. S., \& Suravi, r. h. the rise of a new disaster in Bangladesh: analysis of characteristics and vulnerabilities of lightning during March to September 2018.

28. Wassmann, R., Jagadish, S. V. K., Sumfleth, K., Pathak, H., Howell, G., Ismail, A., \& Heuer, S. (2009). Regional vulnerability of climate change impacts on Asian rice production and scope for adaptation. Advances in Agronomy, 102, 91-133.

29. Zscheischler, J., Westra, S., Van Den Hurk, B. J., Seneviratne, S. I., Ward, P. J., Pitman, A., \& Zhang, X. (2018). Future climate risk from compound events. Nature Climate Change, 8(6), 469-477.

30. Uddin, M. S., \& Suravi, R. H. (2019, January). the rise of a new disaster in Bangladesh: analysis of Characteristics and vulnerabilities of lightning during March to September 2018. In Proceedings on International Conference on Disaster Risk Management (pp. 511516).

31. Holle, R. L., \& Cooper, M. A. (2016). Lightning occurrence and social vulnerability. In Atmospheric Hazards-Case Studies in Modeling, Communication, and Societal Impacts. IntechOpen.

32. Schmidlin, T. W. (2009, December). Risk factors and social vulnerability. In Preprints of the international forum on tornado disaster risk reduction in Bangladesh, Dhaka, Bangladesh. Wind Engineering Research Center, Tokyo Polytechnic University.

33. Dewan, A., Hossain, M. F., Rahman, M. M., Yamane, Y., \& Holle, R. L. (2017). Recent lightning-related fatalities and injuries in Bangladesh. Weather, climate, and society, 9(3), 575-589.

34. Khatun, M., Islam, M. A., \& Haque, M. A. (2016). Studies of thunderstorms and lightning on human health, agriculture and fisheries in Mymensingh and Jamalpur district of Bangladesh. Progressive Agriculture, 27(1), 57-63.

35. Dewan, A., Ongee, E. T., Rafiuddin, M., Rahman, M. M., \& Mahmood, R. (2018). Lightning activity associated with precipitation and CAPE over Bangladesh. International Journal of Climatology, 38(4), 1649-1660. 
36. Holle, R. L., Dewan, A., Said, R., Brooks, W. A., Hossain, M. F., \& Rafiuddin, M. (2019). Fatalities related to lightning occurrence and agriculture in Bangladesh. International Journal of Disaster Risk Reduction, 41, 101264.

37. Karmakar, S., Quadir, D. A., \& Mannan, M. A. (2015). Trends in maximum temperature and thunderstorms, their correlation and impacts on the livelihood of Bangladesh. The Atmosphere, 5(1), 113-129.

38. Karmakar, S., \& Das, M. K. (2020). On the Simulation of Lightning and Flash Flood Producing Thunderstorms in the Northeastern Bangladesh. Journal of Engineering Science, 11(1), 133-146.

39. Umakanth, N., Satyanarayana, G. C., Simon, B., Rao, M. C., \& Babu, N. R. (2020, May). Analysis of lightning flashes over Bangladesh. In AIP Conference Proceedings (Vol. 2220, No. 1, p. 140041). AIP Publishing LLC.

40. Biswas, A., Dalal, K., Hossain, J., Baset, K. U., Rahman, F., \& Mashreky, S. R. (2016). Lightning Injury is a disaster in Bangladesh?-Exploring its magnitude and public health needs. F1000Research, 5.

41. Trengove, E., \& Jandrell, I. R. (2012, September). Leveraging a mobile culture for lightning awareness: the African context. In 2012 International Conference on Lightning Protection (ICLP) (pp. 1-5). IEEE.

42. Dewan, A., Ongee, E. T., Rafiuddin, M., Rahman, M. M., \& Mahmood, R. (2018). Lightning activity associated with precipitation and CAPE over Bangladesh. International Journal of Climatology, 38(4), 1649-1660.

43. Biswas, A., Dalal, K., Hossain, J., Baset, K. U., Rahman, F., \& Mashreky, S. R. (2016). Lightning Injury is a disaster in Bangladesh?-Exploring its magnitude and public health needs. F1000Research, 5.

44. Holle, R. L., Dewan, A., Said, R., Brooks, W. A., Hossain, M. F., \& Rafiuddin, M. (2019). Fatalities related to lightning occurrence and agriculture in Bangladesh. International Journal of Disaster Risk Reduction, 41, 101264.

45. Holle, R. L., Dewan, A., Mohammad, S., Karim, M. R., \& Hosain, M. F. (2018, March). Lightning Fatalities and Injuries in Bangladesh from 1990 through 2017. In 25th International Lightning Detection Conference. 
46. Holle, R. L. (2009, January). Lightning-caused deaths and injuries in and near dwellings and other buildings. In 4th Conference on the Meteorological Applications of Lightning Data (pp. 11-15).

47. Chakravorti, B. K., Sarkar, P., Rahman, A., \& Rahman, A. (2018). Thunderstorm and Lightning: the Temperature Effect on Climate Change of Rangpur Region in Bangladesh. Science Journal of Energy Engineering, 6, 31-36.

48. Mawla, R., Shiblee, M. S. A. A. F., Khan, Z. R., Mamun, M. M. H., Hasan, M., \& Sultana, N. (2018, September). Statistical Analysis of Lightning Myths and Suggestive Measures in Context of Bangladesh. In 2018 4th International Conference on Electrical Engineering and Information \& Communication Technology (iCEEiCT) (pp. 666-671). IEEE.

49. Farukh, M. A., Ahmed, S. U., Islam, M. A., \& Baten, M. A. (2017). Spatial vulnerability assessment of extreme lightning events in Bangladesh using GIS. Journal of Environmental Science and Natural Resources, 10(2), 11-18.

50. Islam, M. S., \& Schmidlin, T. W. (2020). Lightning hazard safety measures and awareness in Bangladesh. Natural Hazards, 101(1), 103-124.

51. Biswas, R. N., Islam, M. N., Mia, M. J., \& Islam, M. N. (2020). Modeling on the spatial vulnerability of lightning disaster in Bangladesh using GIS and IDW techniques. Spatial Information Research, 1-15.

52. Yadava, P. K., Soni, M., Verma, S., Kumar, H., Sharma, A., \& Payra, S. (2020). The major lightning regions and associated casualties over India. Natural Hazards, 101(1), 217-229. 
Figures

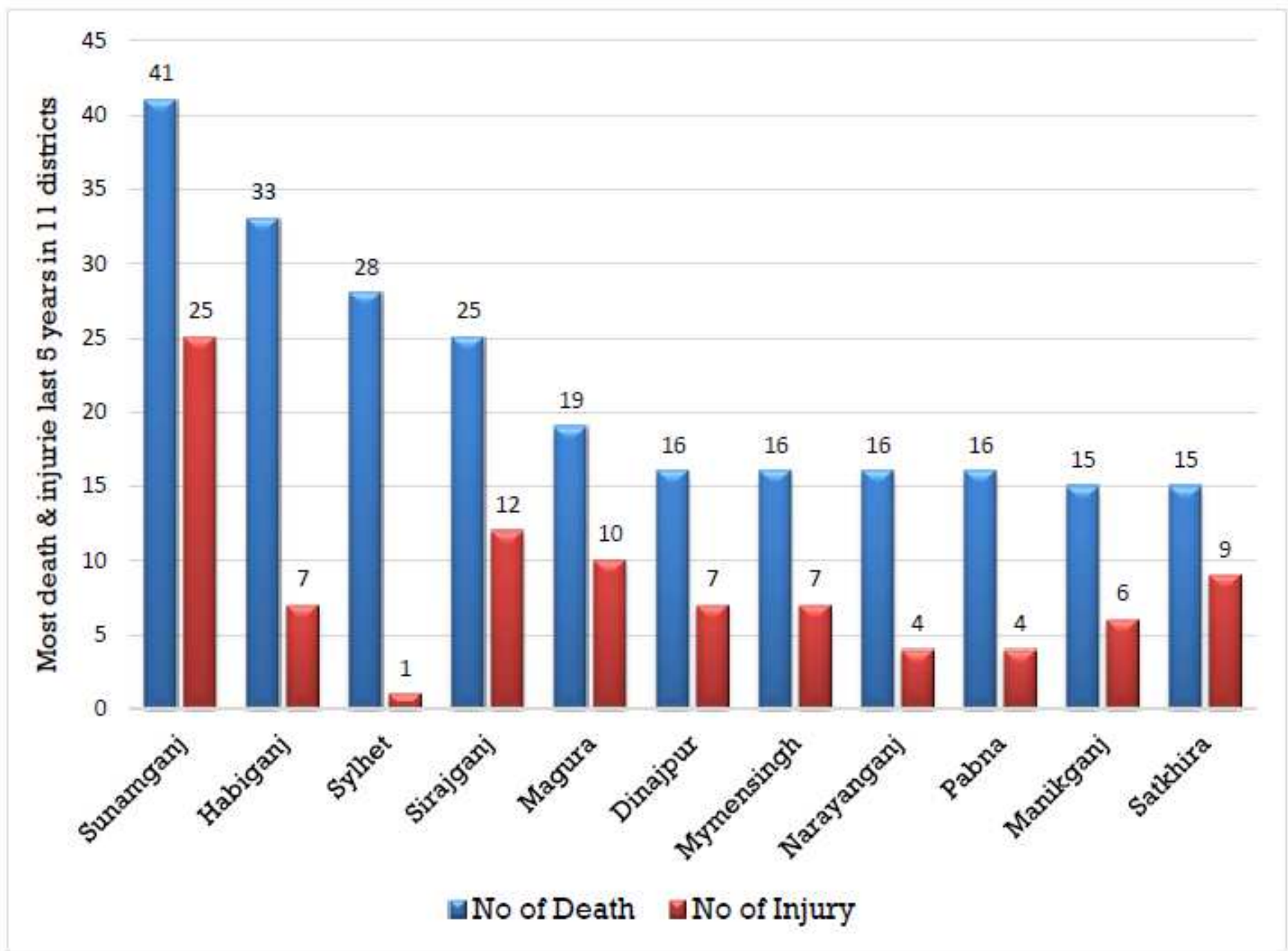

Figure 1

Most Lightning causalities in ten different Districts in Bangladesh (2015-2019) 


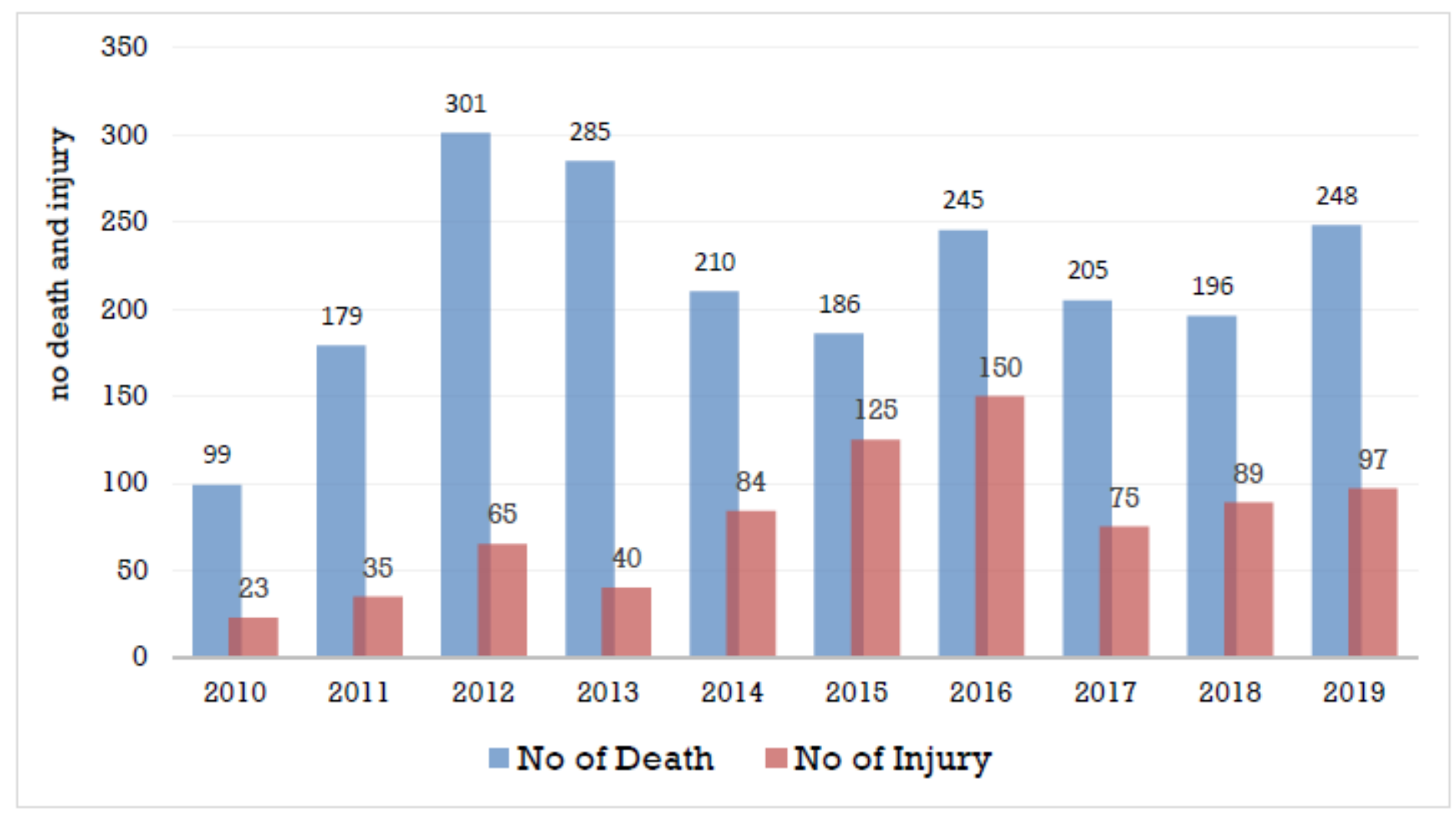

Figure 2

Comparative Causalities from Lightning (2010-2019) in Bangladesh Source: Foundation for Disaster Forum (FDF, 2019 


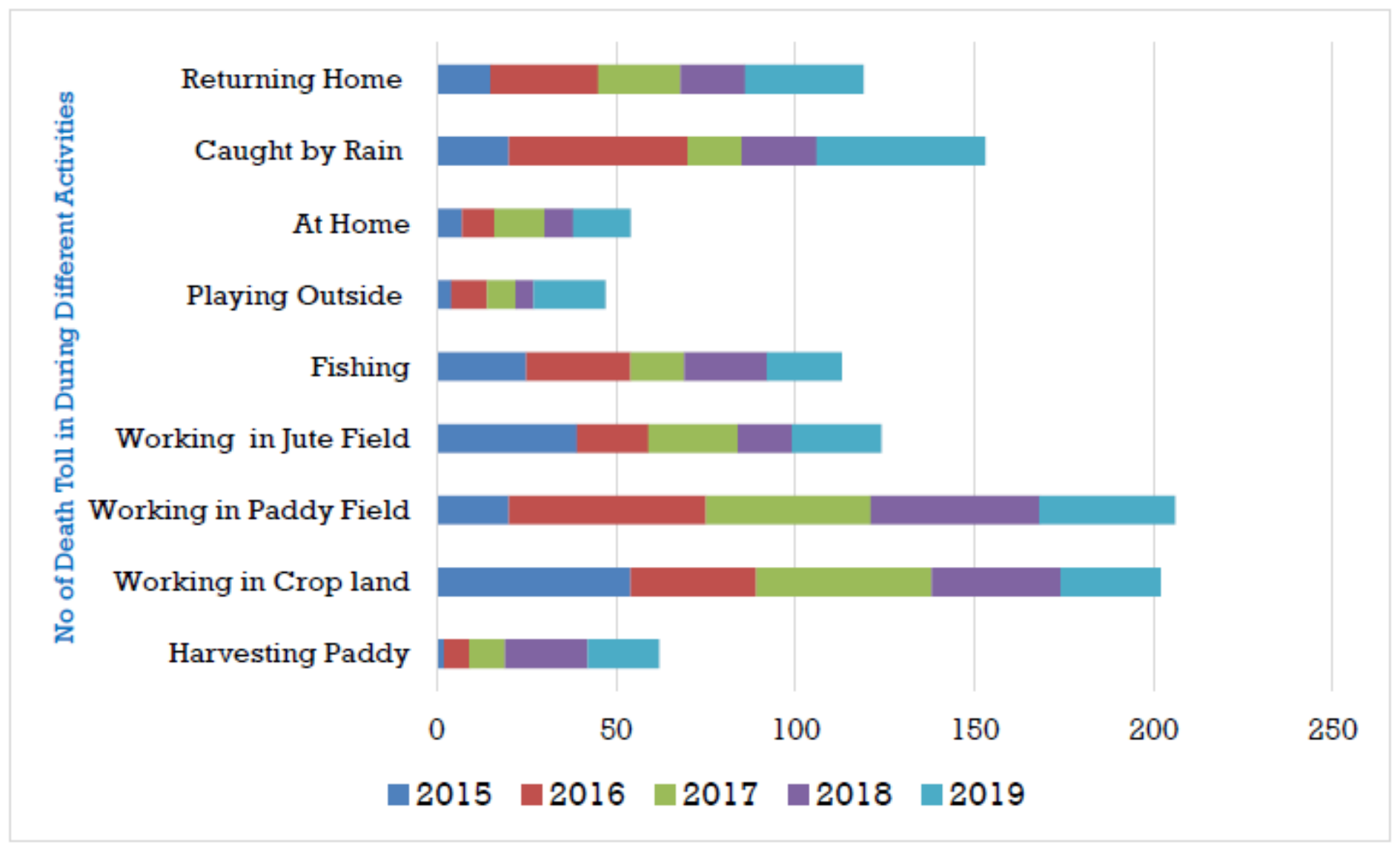

\section{Figure 3}

Lightning Fatalities during Different Activities (2015-2019) 


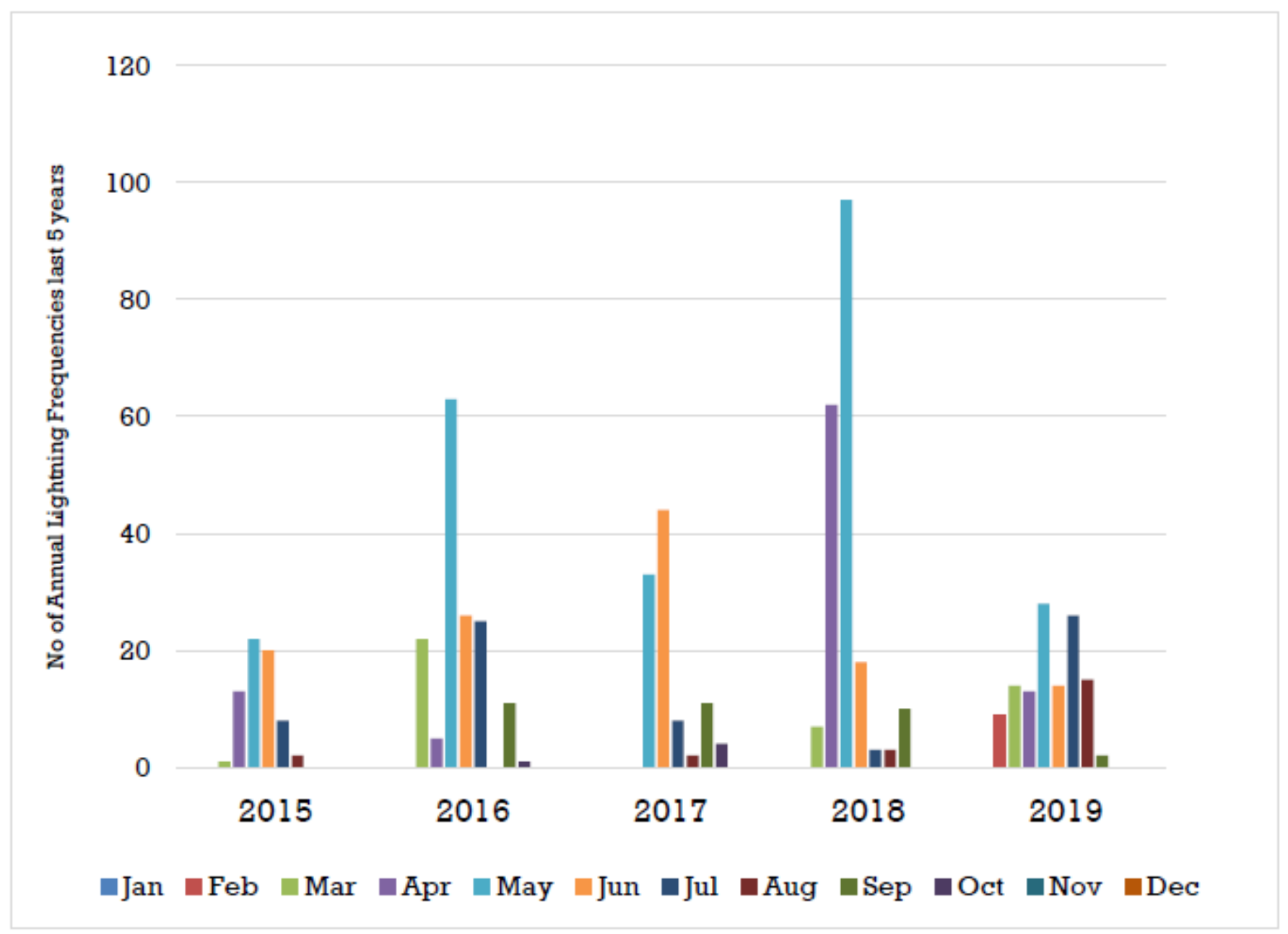

Figure 4

Annual Lightning Frequencies (2015-2019) 


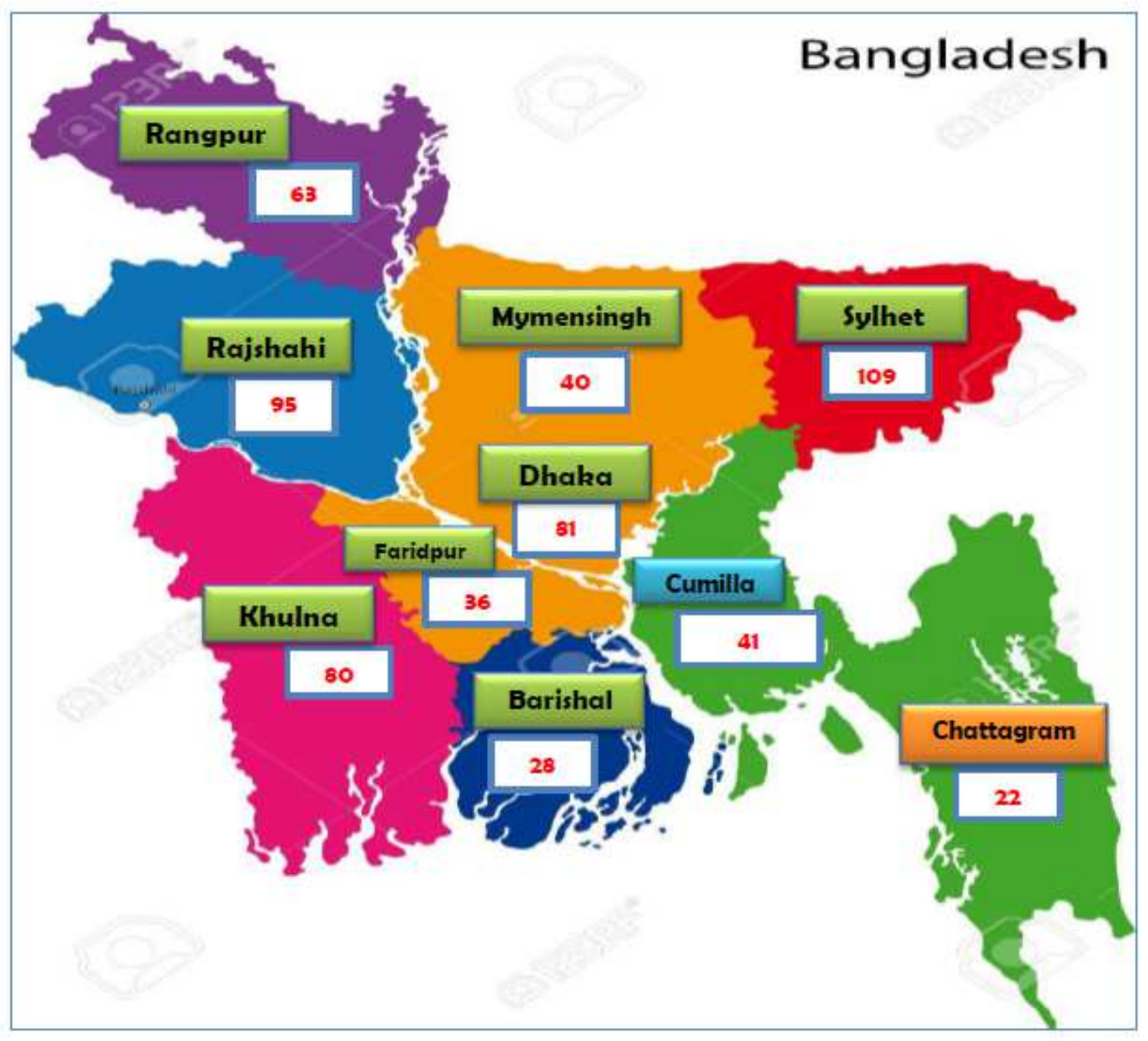

\section{Figure 5}

Death toll from Lightning in Major Divisions (2015-2019) Note: The designations employed and the presentation of the material on this map do not imply the expression of any opinion whatsoever on the part of Research Square concerning the legal status of any country, territory, city or area or of its authorities, or concerning the delimitation of its frontiers or boundaries. This map has been provided by the authors. 


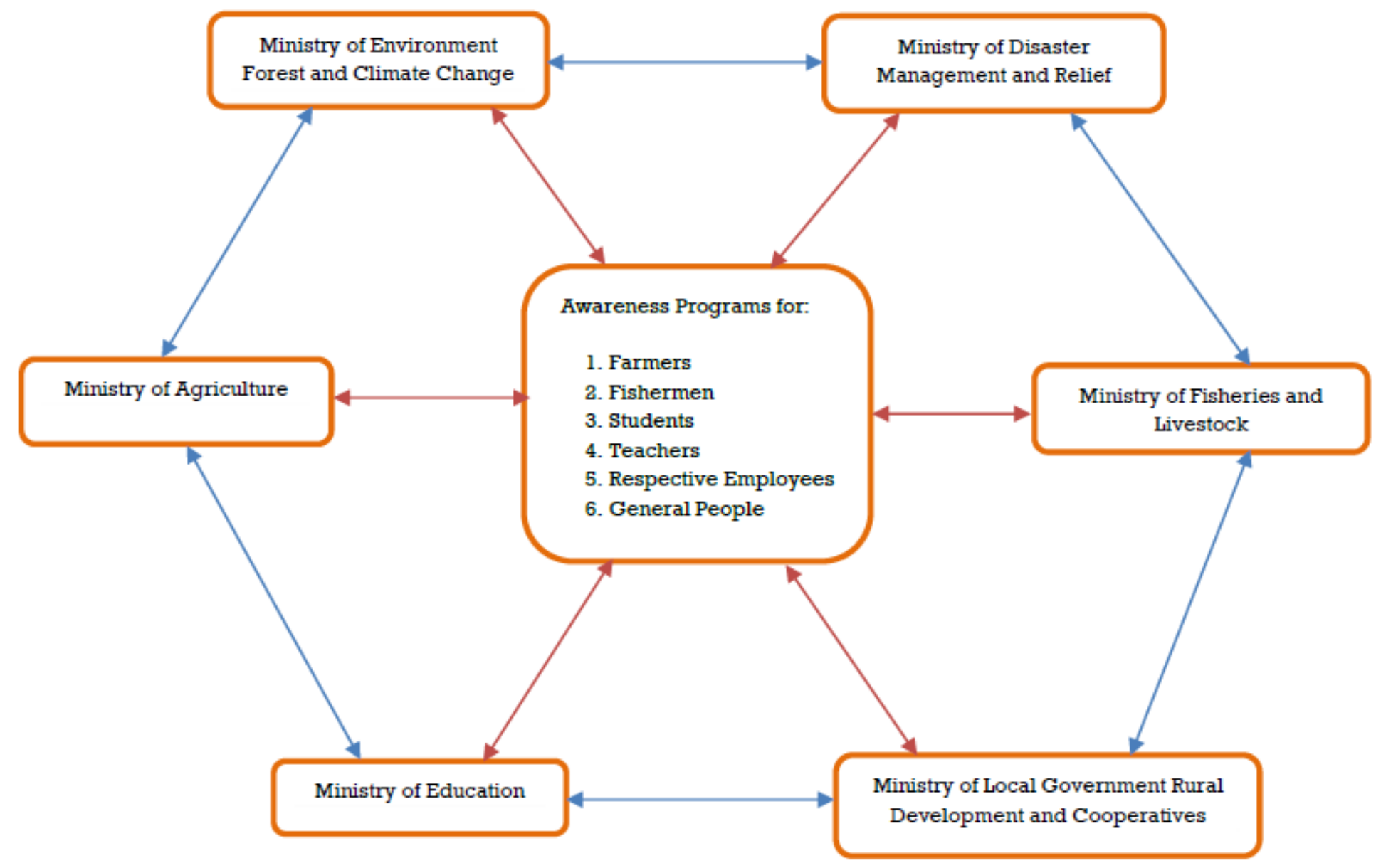

Figure 6

Conceptual Model of Building Awareness for Lightning Fatalities in Bangladesh 